\title{
Big Ideas: Annual Report, 2011
}

Population Council

Follow this and additional works at: https://knowledgecommons.popcouncil.org/ series_newsletters_annualreports How does access to this work benefit you? Let us know!

\section{Recommended Citation}

"Big Ideas: Annual Report, 2011." New York: Population Council, 2012. 


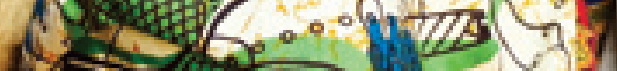

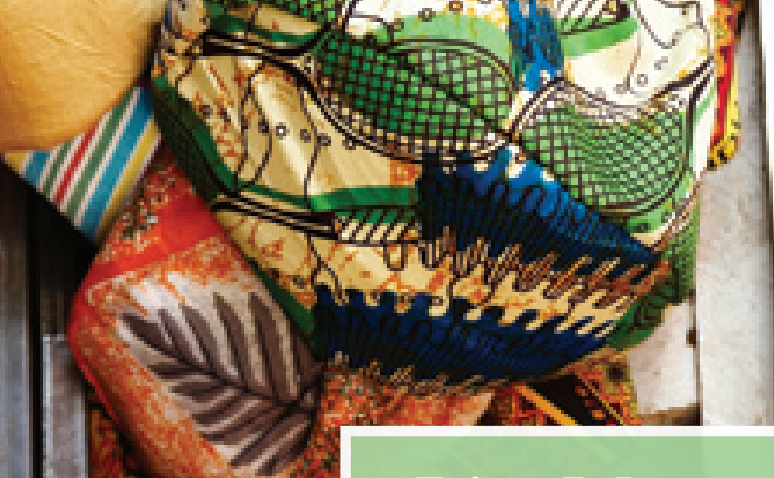

20

is

हn.

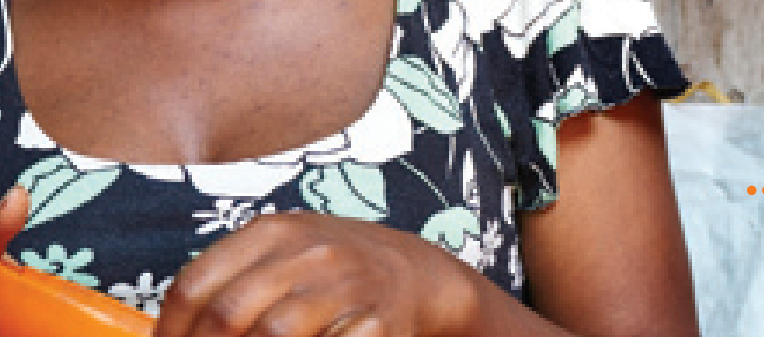

Big Ideas

When women can plan their families, they are healthier and better able to boost their family's income and quality of life. The Population Council has pioneered the design, evaluation, and expansion of voluntary family planning programs, empowering hundreds of millions of women.

Big ideas supported by evidence: It's our model for global change.

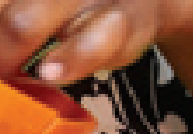

(6)

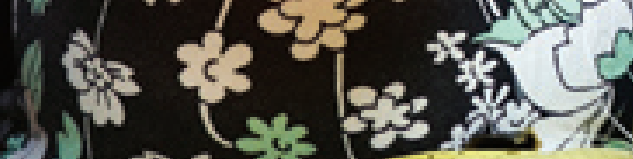

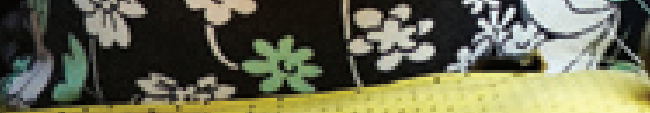

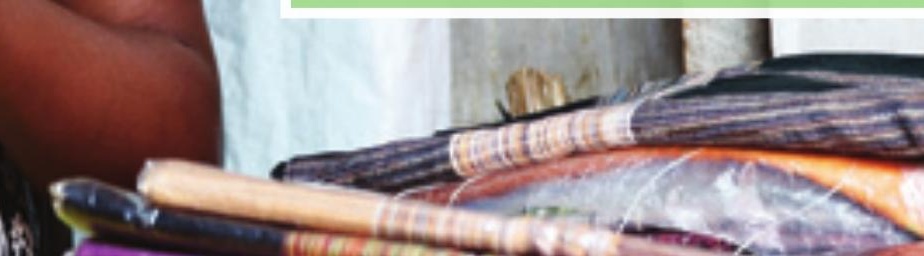


Big Ideas

President's Message

Family Planning:

A Key to Prosperity

2

About the Population Council

6

Reproductive Health

.... Changing the Way Communities

Think about Family Planning 8

.... Defining the Continuum of Care 9

HIV and AIDS

.... Reaching Hidden Populations to Prevent HIV Infection

... Preventing Pregnancy and Sexually Transmitted Infections 11

Poverty, Gender, and Youth

.... Safescaping to Protect Girls 12

.... Safe and Smart Savings 13

2011 Financial Report $\quad 14$

2011 Sources of Support $\quad 18$

Board of Trustees 20

Senior Management 20 
I spent a recent Saturday afternoon looking at antique maps with James Roy, an expert New York dealer. I was particularly intrigued by two maps. The first, published in 1522, depicted an understanding of south and southeast Asian geography essentially unmodified since the second century. The Indian Ocean is closed in the east, creating an inland sea. There is no Japan and no Australia. In the second map, published 70 years later, the world is transformed. The Indian Ocean has opened; Korea and Japan exist and Sumatra, Java, and Borneo have found their proper places. While examining the maps, I thought that what these early mapmakers accomplished in their time is analogous to what the Population Council has accomplished in our time.

The maps clarified the geographic world of the sixteenth century. They moved from a worldview informed by speculation and imagination to an understanding based on observation-what we call research and analysis in modern parlance.

For 60 years, the Population Council has identified important population, health, and development problems and created and evaluated ways to address them. And we have collaborated with government and NGO partners to increase the quality and coverage of family planning, reproductive health, and HIV and AIDS services. Sixty years ago, there were no governmentsponsored family planning programs; no long-acting, reversible contraceptive methods; the determinants and consequences of population change were poorly understood; and high-quality, comprehensive reproductive health programs were unknown in most of the developing world.

This year's annual report focuses on family planning, one of the most consequential of the issues that the Population Council has addressed over the past 60 years. Sixty years ago, doubters argued that women in developing countries wouldn't use family planning and that contraceptive use would not spread until countries modernized. Population Council studies in Bangladesh, Taiwan, and Thailand demonstrated that women wanted to practice family planning and that fertility would decline well in advance of widespread development. Like the early mapmakers, the Population Council changed the way the world thought about critical issues and outlined directions that others could follow.

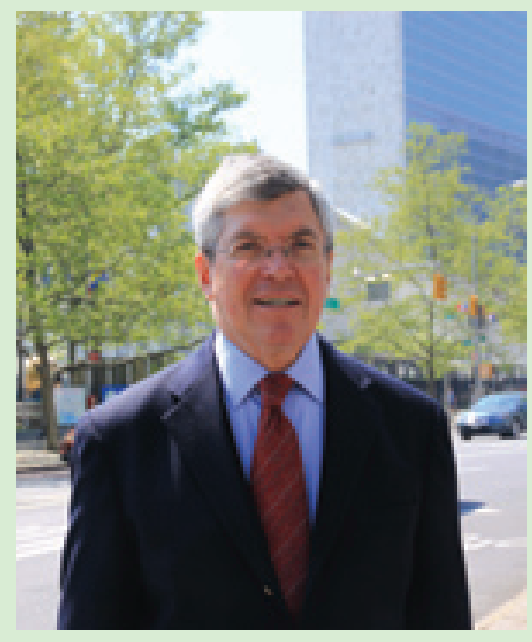

In this report, Council vice president John Bongaarts notes that family planning has been overlooked by many in the development community and describes the ways that family planning can help women, their families, and the societies in which they live. He calls on national governments and international donors to do more to increase access to family planning.

Our 2011 annual report has a streamlined print format and an enhanced on-line presentation. At www.popcouncil.org/ar2011 you can read more about our activities related to family planning and find photos, video clips, data, and thoughtprovoking essays by Council experts on our other research and programs.

Our partners, donors, and friends have greatly increased the effectiveness and impact of our work. We extend our heartfelt appreciation to our supporters. Your help has allowed us to chart a new world and to help deliver solutions that have benefited hundreds of millions of people. We look forward to more years of discovery and collaboration.

Peter J. Donaldson 


\section{Family Planning: A Key to Prosperity}

BY JOHN BONGAARTS

Family planning programs are highly cost-effective, have demonstrable poverty-reducing effects, and provide important health and human rights benefits to those who would otherwise have trouble achieving them. Yet international support for such programs has not kept pace with the need. As a result, many developing countries, particularly in sub-Saharan Africa, continue to face rapid population growth and other impediments to social and economic development.

The Population Council has worked for many decades to improve family planning services, empower women, and increase contraceptive choice so that women who want to avoid pregnancy can do so. Our work has played a pivotal role in defining the ability of family planning to improve lives and strengthen societies. We are encouraged to see some of the world's major donors-such as the U.S. government and the World Bank-starting to take a renewed interest in this issue.

But much more must be done.

Some 215 million women in the developing world do not want to get pregnant but are not using an effective method of contraception, resulting in unintended pregnancies and preventable maternal and infant deaths. The poorest parts of

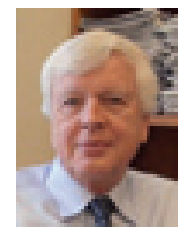

John Bongaarts is a Population Council vice president and distinguished scholar. His research focuses on the determinants of fertility, population-environment relationships, the demographic impact of the AIDS epidemic, population aging, and population policy options in the developing world.

the world-where individuals are already struggling to overcome hunger-will see continued population growth of more than 70 million per year. The population of subSaharan Africa is expected to increase by 1 billion by 2050 . And high unemployment and inequality among rapidly growing young populations are contributing to the spread of political violence and civil strife. 


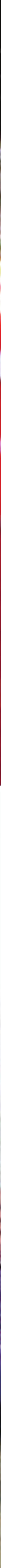


Family planning does more than provide health benefits; these programs also reduce poverty and improve lives:

........ $\because$ First, by reducing the birth rate, family planning programs can create a "demographic dividend" that boosts economic growth for a few decades by increasing the size of the labor force relative to both young and old dependents, and by making it possible for people to save money. About a third of the rapid economic growth rates experienced in recent decades by East Asian tiger economies is the result of this dividend.

....... Second, slower population growth allows families and communities to invest more in providing quality education and health care and to improve infrastructure.

Children who are healthy and educated are primed to become productive adults who can help to fuel the economy.

........ Third, when families are able to plan and space their pregnancies, they can invest more in each family member.

And women who have fewer children have more time to earn wages outside the home, which boosts family income and quality of life and reduces poverty.

The Population Council documented these benefits of family planning in studies of a landmark project undertaken by the International Centre for Diarrhoeal Disease Research, Bangladesh (icddr,b) in the Matlab district of Bangladesh. The Matlab population of 173,000 people was divided into two areas: an experimental area, where access to high-quality family planning services was greatly expanded to include home visits, a wide array of contra- ceptive choices, and follow-up care; and a control area, which received the standard set of less-intensive services that were available country-wide.

The Council's research showed that the impact in the experimental area was large and immediate: contraceptive use increased markedly, fertility declined rapidly, and women's health, household earnings, and use of preventive health care improved. Children living in households that received family planning outreach were more likely to survive to the age of five and to attend school than were children from households that did not participate.

The program was so successful that it was expanded across the country, with extensive technical assistance and support from the Population Council. Today, Bangladesh is widely recognized as a world leader in family planning. We have learned that robust, high-quality voluntary family planning programs are among the most important policy responses for improving the lives of people in developing countries. As in Bangladesh, in other countries that adopted voluntary family planning programs-such as Indonesia, Kenya, and Rwanda-economies, public health, and standards of living are improving.

The argument for investing in family planning is persuasive: women and children, communities, and societies all benefit. Family planning should be a high policy priority and should be seen not only in terms of its benefits to people's health and rights, but as a critical investment in economic development and higher living standards. Around the world, the Council continues to work closely with ministries of health and other local partners to fight poverty by strengthening health systems, with a special focus on increasing access to family planning and improving reproductive health. 


\section{Investing in voluntary family planning is one of the most cost-effective ways to address global development challenges.}

\section{Family planning services}

Reduce unmet need for contraception

Reduce unintended pregnancy

Reduce birth rates and slow population growth

\section{Improve} health

\section{Empower} women

Boost

economic growth

\section{Benefit} communities
Reduce maternal mortality

Improve infant and child health

Reduce abortion

Reach desired family size

Invest in individual children

Increase work productivity

Increase size of labor force

Increase savings

Reduce poverty

Enhance schooling and health care

Improve infrastructure

Reduce pressure on natural resources 


\section{The Population Council conducts biomedical, social science, and public health research. We deliver solutions that lead to more effective policies, programs, and technologies that improve lives around the world.}

\section{Tackling tough challenges}

The Population Council's Reproductive Health program strives to improve sexual and reproductive health, especially for vulnerable people in developing countries. We help individuals to achieve their family planning and reproductive health goals through improvements in technologies and services. We work to reduce maternal mortality and morbidity.

Our HIV and AIDS program is devoted to understanding and slowing the spread of the HIV epidemic. Through biomedical and behavioral research, we expand access to innovative and effective products and services.

Our Poverty, Gender, and Youth program seeks to understand and address the social dimensions of poverty, the causes and consequences of gender inequality, the disparities in opportunity that arise during adolescence, and the critical requirements for reaching a successful, productive adulthood in developing countries.

\begin{abstract}
Established in 1952, the Population Council is governed by an international board of trustees. Its New York headquarters supports a global network of country offices. The Council staff consists of more than 600 women and men from 32 countries. More than 60 percent are based outside the United States. Council staff members conduct research and carry out programs in more than 50 countries.
\end{abstract}

\section{Delivering solutions}

Population Council staff identify neglected health and development problems; work with developing-country partners to design, implement, and test pilot programs to address these challenges; conduct biomedical research to develop new contraceptives and microbicides; inform policymakers, program managers, the scientific community, and the public about the results of our research; collaborate with governments and nongovernmental organizations to expand successful pilot programs and to improve large-scale programs; and collaborate with pharmaceutical companies to ensure that our products are available to the poorest and most vulnerable people worldwide. 


\section{Sharing knowledge}

The Population Council publishes two widely read and influential peer-reviewed scientific journals: Population and Development Review and Studies in Family Planning. The Council also maintains a website and produces books, working papers, newsletters, reports, slide shows, software, and toolkits. A database of our publications is provided at www.popcouncil.org/ pubsearch.

\section{Improving programs}

The Population Council's work does not end with conducting research. We strive to ensure that our findings get translated into concrete improvements in policies and programs. We provide technical assistance to strengthen national programs, and we offer expertise in scaling up effective and sustainable interventions, implementing systems to monitor and evaluate projects, and finding innovative ways to cover the costs of care.

\section{Strengthening resources}

The Population Council helps to improve the research capacity of reproductive and population scientists in developing countries through grants, fellowships, apprenticeships, and support to research centers. The Population Council's fellowship programs have helped advance the careers of thousands of social and biomedical scientists, public health researchers, and program managers, many of whom have gone on to hold leadership positions. In 2011, we supported more than 30 fellows.

\section{Forming partnerships}

Achieving our ambitious mission is only possible in partnership with governments, universities, foundations, public and private health networks, hospitals, research centers, nongovernmental organizations, and individuals from around the world. These partnerships represent one of the most influential ways in which we improve services and create lasting change. Through our partnerships, we support sound practices and efforts to increase the scope of highly effective programs. 
$\because \because 2011$ HIGHLIGHTS: REPRODUCTIVE HEALTH

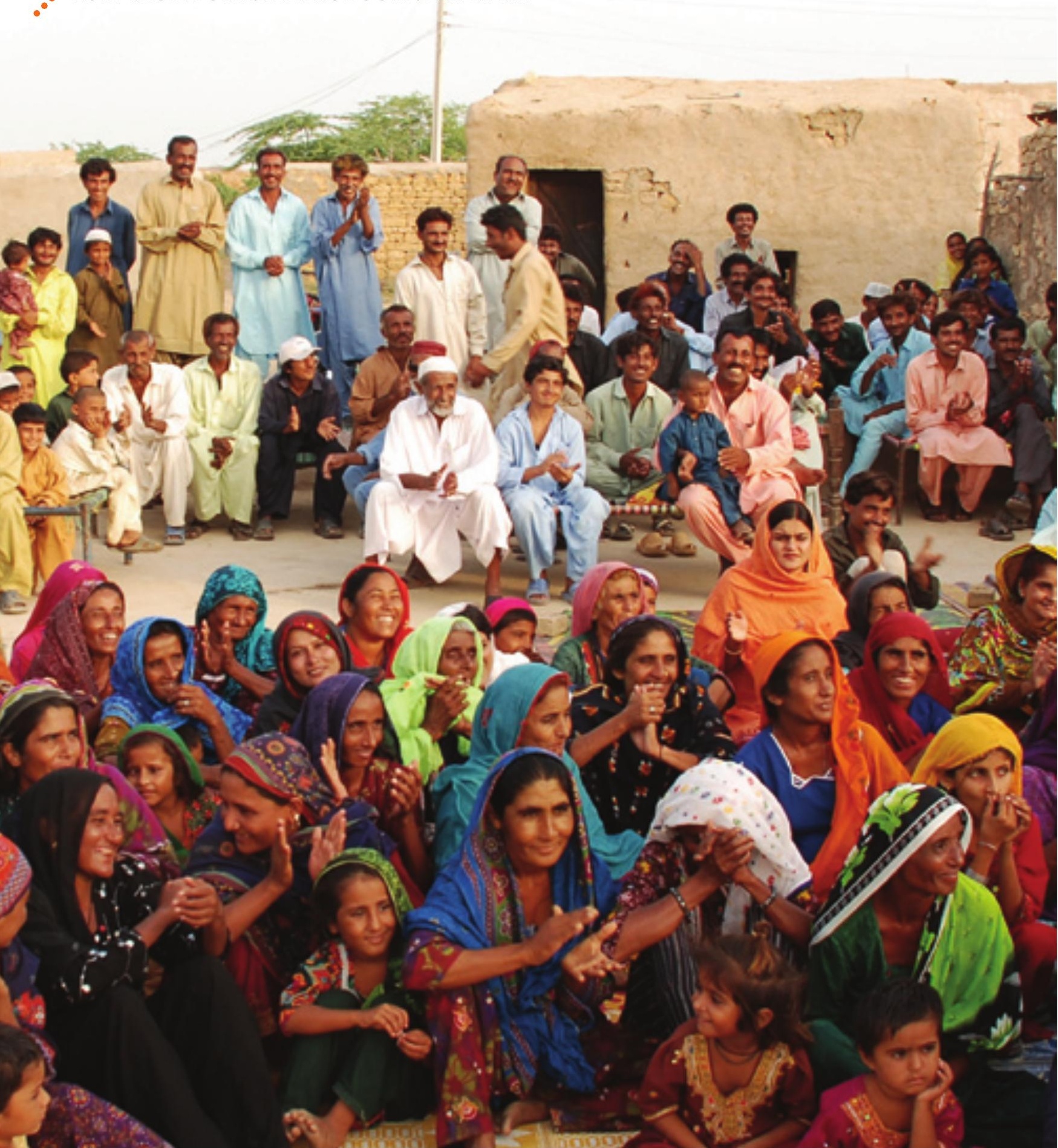

Changing the Way Communities Think about Family Planning

The Population Council completed the highly successful Family Advancement for Life and Health (FALAH) project in 2011. This family planning initiative increased contraceptive use by 28 percent in less than four years in conservative areas of Pakistan, with the highest increases among poor, rural, and younger couples. The project promoted the idea of healthy "birth spacing" to protect women and infants, and engaged the support of religious leaders who exert strong influence over family planning decisions. Government health ministers are committed to expanding the FALAH approach nationwide with support from development partners. 

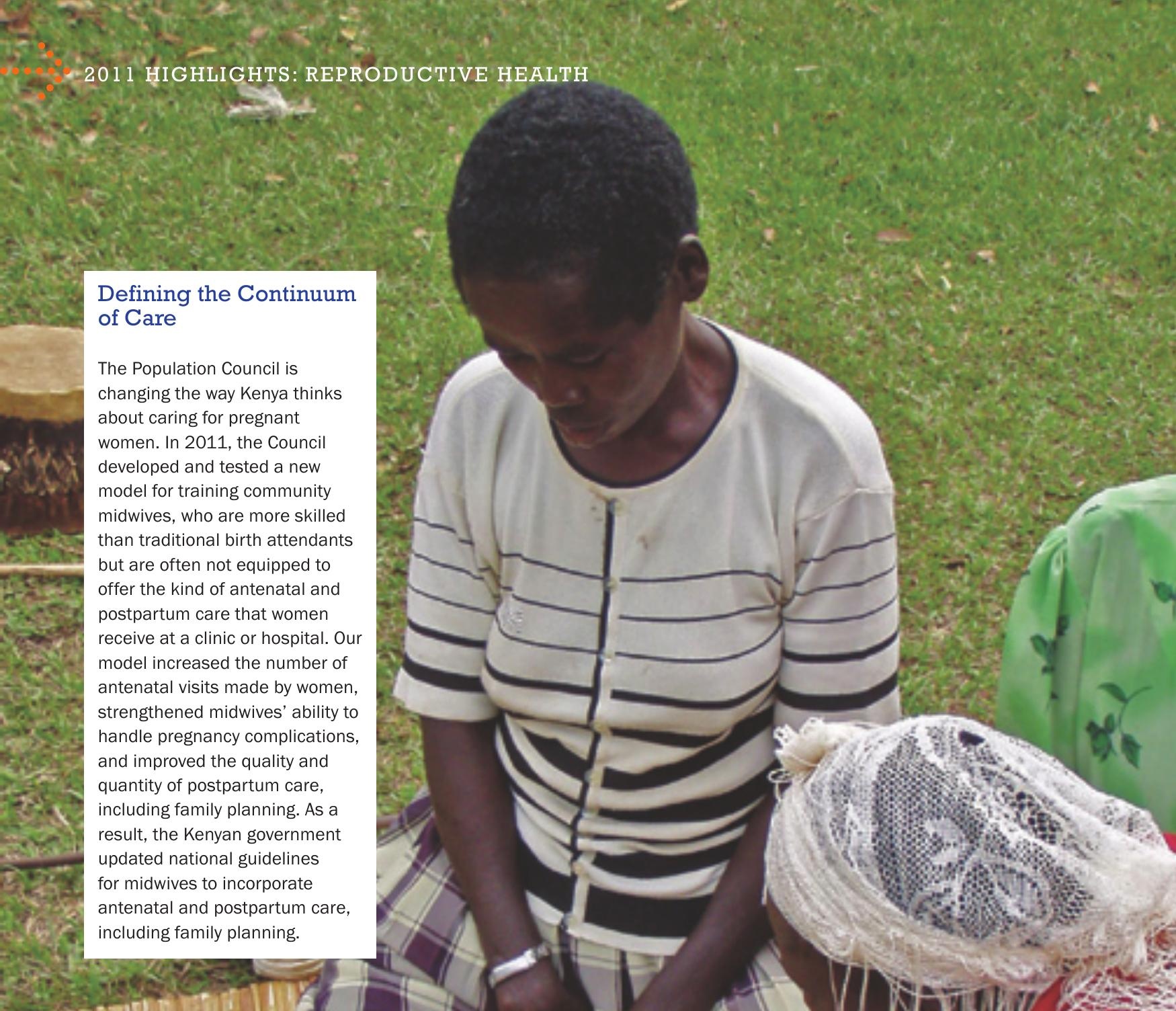

changing the way Kenya thinks about caring for pregnant women. In 2011, the Council ped and tested a new than traditional birth attendants postpartum care that women receive at a clinic or hospital. Our and improved the quality and quantity of postpartum care antenatal and postpartum care, including family planning. 


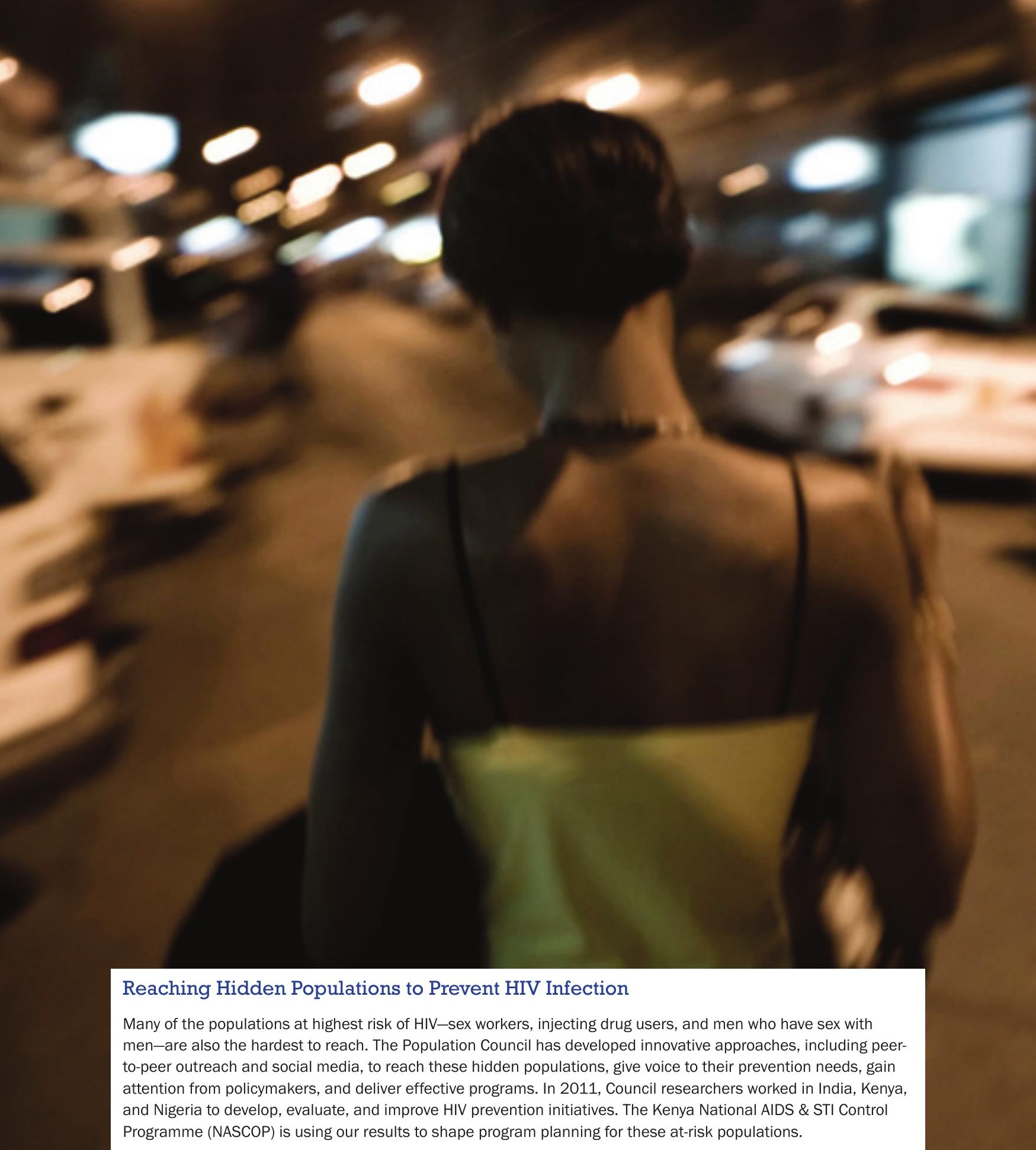





\section{HIGHLIGHTS: POVERTY, GENDER, AND YOUTH}

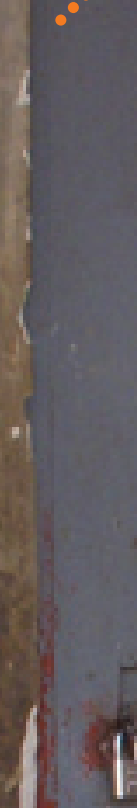




\section{FINANCIAL REPORT}

I am pleased to report that future funding commitments made by donors increased by nearly 40 percent, from $\$ 42.8$ million in 2010 to $\$ 59.3$ million in 2011 . The number of awards increased by 41 percent. These increases help maintain the Council's financial health and ensure that we have the resources to continue our vital work. The chart on the following page provides information on the Council's sources of support.

Program spending in 2011 totaled $\$ 72.3$ million, representing 85 percent of the Council's total operating expenses. For every dollar spent, 85 cents goes directly to research and programs, demonstrating our commitment to our mission. Continued improvements in infrastructure have led to greater operational efficiencies in the Council's management, resulting in a decline in supporting services costs.

As a consequence of market volatility, the Council's investment portfolio experienced a $\$ 4.6$ million decline. We closely monitor the Council's financial status and remain committed to the fiscal discipline necessary to maintain our record of accomplishments. Readers interested in learning more about the Council's finances can consult our website (http://popcouncil.org/who/financials.asp).

I would be pleased to answer any questions and can be reached at snewman@popcouncil.org.

Scott Newman

Chief Financial Officer and Treasurer 


\section{SOURCES OF SUPPORT \\ TOTAL \$64.4 MILLION}

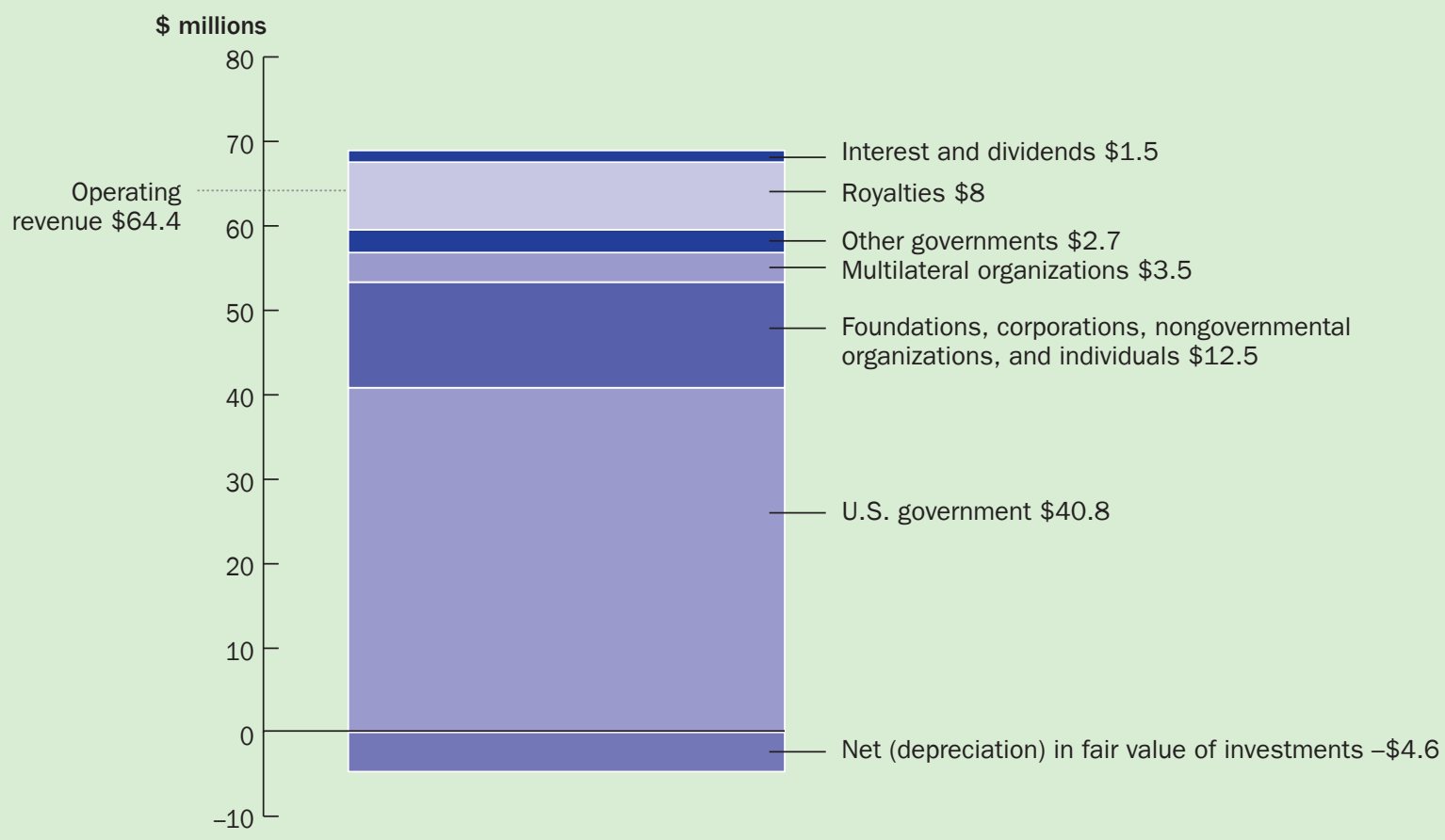

USES OF FUNDS

TOTAL \$85 MILLION

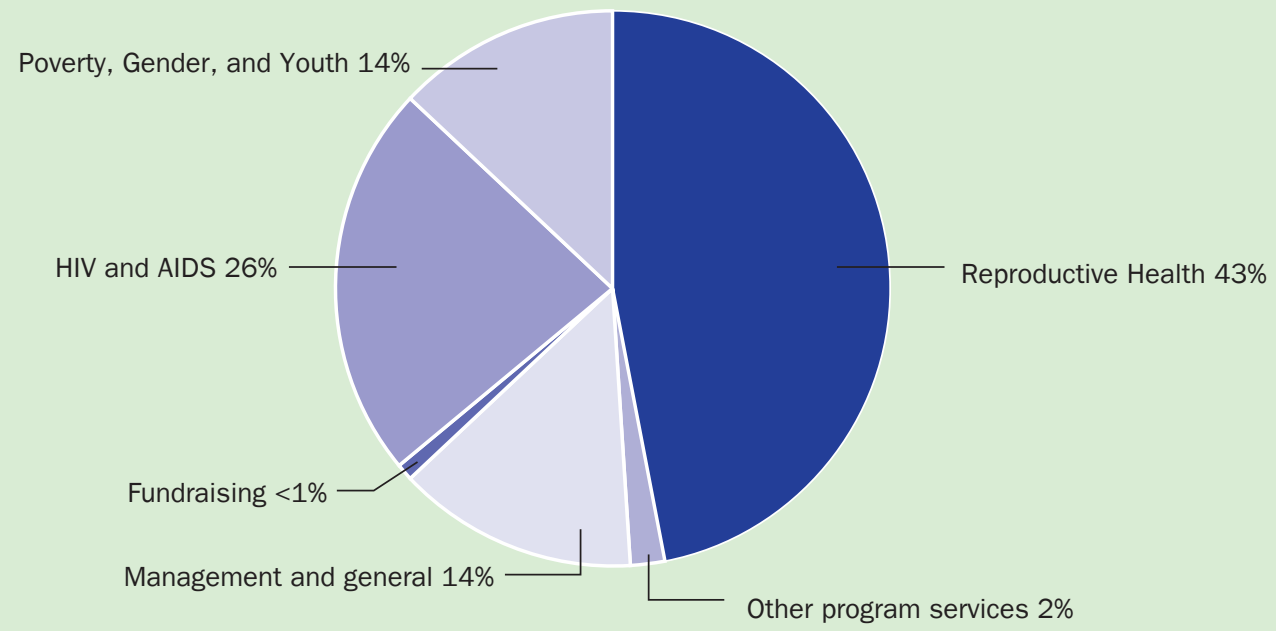




\begin{tabular}{|c|c|c|c|c|c|c|}
\hline & \multicolumn{3}{|c|}{ Unrestricted } & \multicolumn{3}{|c|}{ Restricted } \\
\hline & $\begin{array}{r}\text { General } \\
\text { undesignated }\end{array}$ & $\begin{array}{r}\text { The John D. } \\
\text { Rockefeller 3rd } \\
\text { Memorial Fund } \\
\text { and others }\end{array}$ & Total & $\begin{array}{l}\text { Temporarily } \\
\text { restricted }\end{array}$ & $\begin{array}{l}\text { Permanently } \\
\text { restricted }\end{array}$ & Total \\
\hline \multicolumn{7}{|l|}{ OPERATING REVENUE } \\
\hline Grants and contributions & $\$ 56,317,571$ & 3,600 & $56,321,171$ & $3,019,250$ & - & $59,340,421$ \\
\hline Royalties & $8,037,748$ & - & $8,037,748$ & - & - & $8,037,748$ \\
\hline $\begin{array}{l}\text { Interest and dividends (net of } \\
\$ 192,770 \text { investment fees) }\end{array}$ & 15,870 & $1,098,645$ & $1,114,515$ & 393,584 & - & $1,508,099$ \\
\hline $\begin{array}{l}\text { Net appreciation (depreciation) } \\
\text { in fair value of investments }\end{array}$ & 68,237 & $(3,782,646)$ & $(3,714,409)$ & $(867,587)$ & - & $(4,581,996)$ \\
\hline Other & 142,607 & - & 142,607 & - & - & 142,607 \\
\hline Net assets released from restrictions & $17,322,635$ & - & $17,322,635$ & $(17,322,635)$ & - & - \\
\hline TOTAL OPERATING REVENUE & $81,904,668$ & $(2,680,401)$ & $79,224,267$ & $(14,777,388)$ & - & $64,446,879$ \\
\hline \multicolumn{7}{|l|}{ OPERATING EXPENSES } \\
\hline \multicolumn{7}{|l|}{ Program services } \\
\hline HIV and AIDS & $22,505,317$ & - & $22,505,317$ & - & - & $22,505,317$ \\
\hline Poverty, Gender, and Youth & $11,731,872$ & - & $11,731,872$ & - & - & $11,731,872$ \\
\hline Reproductive Health & $36,477,107$ & - & $36,477,107$ & - & - & $36,477,107$ \\
\hline Distinguished Colleagues & 320,300 & - & 320,300 & - & - & 320,300 \\
\hline Publications & $1,286,563$ & - & $1,286,563$ & - & - & $1,286,563$ \\
\hline TOTAL PROGRAM SERVICES & $72,321,159$ & - & $72,321,159$ & - & - & $72,321,159$ \\
\hline \multicolumn{7}{|l|}{ Supporting services } \\
\hline Management and general & $11,505,314$ & 569,435 & $12,074,749$ & - & - & $12,074,749$ \\
\hline Fundraising & 549,029 & - & 549,029 & - & - & 549,029 \\
\hline TOTAL SUPPORTING SERVICES & $12,054,343$ & 569,435 & $12,623,778$ & - & - & $12,623,778$ \\
\hline TOTAL OPERATING EXPENSES & $84,375,502$ & 569,435 & $84,944,937$ & - & - & $84,944,937$ \\
\hline $\begin{array}{l}\text { Deficiency of operating revenue } \\
\text { over operating expenses }\end{array}$ & $(2,470,834)$ & $(3,249,836)$ & $(5,720,670)$ & $(14,777,388)$ & - & $(20,498,058)$ \\
\hline \multicolumn{7}{|l|}{ Other changes in net assets: } \\
\hline $\begin{array}{l}\text { Gain on lease obligation and other, } \\
\text { net }\end{array}$ & 520,763 & - & 520,763 & - & - & 520,763 \\
\hline $\begin{array}{l}\text { Pension and other postretirement } \\
\text { charges other than net periodic } \\
\text { benefit cost }\end{array}$ & $(3,111,204)$ & - & $(3,111,204)$ & - & - & $(3,111,204)$ \\
\hline Write-off of contribution receivable & $(331,062)$ & - & $(331,062)$ & - & - & $(331,062)$ \\
\hline Transfer from endowments & $1,725,554$ & $(915,910)$ & 809,644 & $(809,644)$ & - & - \\
\hline DECREASE IN NET ASSETS & $(3,666,783)$ & $(4,165,746)$ & $(7,832,529)$ & $(15,587,032)$ & - & $(23,419,561)$ \\
\hline \multicolumn{7}{|l|}{ NET ASSETS AT BEGINNING } \\
\hline OF YEAR & $8,370,340$ & $74,626,427$ & $82,996,767$ & $38,829,356$ & $5,485,776$ & $127,311,899$ \\
\hline NET ASSETS AT END OF YEAR & $\$ 4,703,557$ & $70,460,681$ & $75,164,238$ & $23,242,324$ & $5,485,776$ & $103,892,338$ \\
\hline
\end{tabular}


BALANCE SHEET (For the year ended December 31, 2011)

Total

\section{ASSETS}

Cash and cash equivalents

Grants and contributions receivable, net

U.S. government agencies

$6,912,110$

Other

Other receivables

$3,158,237$

Prepaid expenses and other assets

Postretirement medical benefits trust

Investments

$92,056,882$

Fixed assets, net

$6,546,028$

TOTAL ASSETS

\section{LIABILITIES AND NET ASSETS}

Liabilities

Accounts payable, accrued expenses, and other liabilities

$\$ 4,895,120$

Awards, contracts, and fellowships payable

$5,915,559$

Program advances

$8,708,840$

Loan payable

$1,506,000$

Deferred rent credit

$1,004,137$

Accrued lease obligation

773,118

Postretirement medical benefits payable

$9,252,499$

TOTAL LIABILITIES

$32,055,273$

Net assets

Unrestricted

General undesignated

$4,703,557$

The John D. Rockefeller 3rd Memorial Fund and others

SUBTOTAL UNRESTRICTED

$75,164,238$

Restricted

Temporarily restricted

$23,242,324$

Permanently restricted

A copy of the audited financial statements, prepared in accordance with U.S. generally accepted accounting principles, is available upon request from Population Council, One Dag Hammarskjold Plaza, New York, New York 10017, and can be accessed online at www.popcouncil.org. 


\section{SOURCES OF SUPPORT}

Funding for the Population Council's work was generously provided by the government agencies, multilateral organizations, foundations, corporations, and individuals listed here. This support allows the Council to deliver solutions to critical health and development challenges and improve lives. We greatly appreciate all contributions and thank our donors for their support.

\section{GOVERNMENTS AND GOVERNMENTAL AGENCIES \\ Government of Burkina Faso \\ - Ministry of Health \\ Government of the \\ Netherlands \\ - Embassy of the Kingdom of the Netherlands \\ Government of Sweden \\ - Swedish International Development Cooperation Agency \\ - Swedish Ministry for Foreign Affairs \\ Government of the United \\ Kingdom \\ - Department for International Development \\ Government of the United \\ States \\ - Agency for International Development \\ - Centers for Disease Control and Prevention \\ - National Institutes of Health}

\section{MULTILATERAL}

ORGANIZATIONS

Financial Education Fund (FEF)

Global Network of People Living with HIV/AIDS (GNP+)

International Consortium for Emergency Contraception (ICEC)

Joint United Nations Programme on HIV/AIDS (UNAIDS)

Poverty and Economic Policy Research Network (PEP)

United Nations Capital Development Fund (UNCDF)

United Nations Children's Fund (UNICEF)

United Nations Development Programme (UNDP)

United Nations Foundation (UNF)

United Nations Population Fund (UNFPA)

UN Women

World Bank Group

World Health Organization
FOUNDATIONS/

CORPORATIONS/OTHER

NONGOVERNMENTAL

ORGANIZATIONS

Albert Einstein College of

Medicine

Anonymous

Association of Volunteers in International Service (AVSI)/ Uganda

The Atlantic Philanthropies

Bayer Schering Pharma AG

Better World Fund

The Fred H. Bixby Foundation

Boston University School of

Public Health

Centro de Investigaciones

y Estudios Superiores

en Antropología Social (CIESAS)

The William H. Donner

Foundation

Elton John AIDS Foundation

Emory University

EngenderHealth

Equality Now

Feed the Minds

FHI 360

The Ford Foundation

H. B. Fuller Foundation

Bill \& Melinda Gates

Foundation

Girl Hub

Global Giving

Guttmacher Institute

Health Decisions

The William and Flora

Hewlett Foundation

HRA Pharma

Institute of International

Education

International Centre for

Diarrhoeal Disease

Research, Bangladesh (icddr,b)

International Development Research Centre (IDRC)

International Partnership for Microbicides, Inc. (IPM)

International Planned

Parenthood Federation (IPPF)

International Rescue

Committee (IRC)
IntraHealth

Ipas

Jacobs Foundation

The Johns Hopkins University

Levi Strauss \& Co.

Foundation

The Libra Foundation

London School of Hygiene \& Tropical Medicine - LSHTM

Los Angeles Biomedical

Research Institute at Harbor-UCLA

The John D. and Catherine T. MacArthur Foundation

Magee-Women's Research Institute and Foundation MWRIF

Marie Stopes International (MSI)

New York University (NYU)

Nike Foundation

NoVo Foundation

The David \& Lucile Packard Foundation

Partridge Foundation

PATH

Pathfinder International

Population Services International (PSI)

Research \& Advocacy Fund (RAF) of the British Council

Research Triangle Institute International (RTI)

The Rockefeller Foundation

Society for Family Health (SFH)

Standard Chartered Bank

Summit Foundation Inc.

Syria Trust for Development

Unbound Philanthropy

University of California at San Francisco

University of Connecticut Health Center

University Research Co., LLC

ViiV Healthcare

Wallace Global Fund

\section{INDIVIDUAL}

DONORS AND

FAMILY FOUNDATIONS

John D. Rockefeller 3rd

Visionaries

Anonymous (3)

Avis and Clifford Barrus

Medical Foundation

The Max and Victoria Dreyfus

Foundation

George and Patricia Ann

Fisher Foundation

F. M. Kirby Foundation

The Shenandoah

Foundation*

The Abby R. Mauzé Trust*

Millstream Fund*

Stavros S. Niarchos

Foundation

Estate of William O'Callaghan

The Blanchette Hooker

Rockefeller Fund

Seymour and Kate Weingarten

President's Laureates

Anonymous (8)

Tammy Allen and Daniel Gropper

Jane V. Andrews and Robert

R. Andrews Fund of The

Minneapolis Foundation

Brian Arbogast and Valerie Tarico

D. Euan Baird

George P. and Ching-Ching Cernada*

Jerry and Diane

Cunningham*

Barbara B. Ebert*

Robert W. Gillespie

JJ Charitable Foundation

Laura Scheuer

Frederick $\mathrm{H}$. and Nancy Link Schmidt*

Sukey N. Wagner*

Rena J. Zieve and Dr. Greg J. Kuperberg* 
Council Champions

Anonymous (7)

Sandra P. and Lawrence Arnold*

Shawky Badawy

Michael Baird

Milton Barber

John R. Bermingham*

Thomas S. Blount

Andrew M. Boas*

John and Zenaida Bongaarts

Willard B. Brown

Caithness Foundation, Inc.

Paul Demeny

Peter J. and Nancy

Donaldson*

Barbara B. Ebert*

Eco Trust*

Andrea Eschen

Rosemary Faulkner

Glen M. Feighery*

Gary and Kristen Friedman

The Glickenhaus Foundation

William M. Grady and Karen

Tsuchiya*

David Grill

Sheila Gudiswitz

Angel Gurria

Elizabeth A. Hallin

Helen R. Hauge*

Paul C. Haughey*

The William W. Hildreth Fund of Fidelity Investments

Charitable Gift Fund

Kaplan Sisters Foundation

Carl E. Kessler Family Foundation

Kyung J. Kim*

Margaret A. Knoll

Wayne V. Krill

George Krumme

McBride Family and Aspen

Airport Business Center

Foundation

John M. and Renate E. Mirsky*

Carol and Daniel Mishell, Jr.

Samarendranath and Rekha Mitra*

Ursula and Paul Ofman

Wanda J. Olson

Osgrodd Foundation*

Mary Catherine Phinney

Marnie S. Pillsbury*

J. Edson Pinto

Lyle H. Ramshaw*

James S. and Amy H. Regan

Alison J. Renner

Thomas L. Richie and Diane Pascal*

Julie A. Robichaud*
David Rockefeller*

Matthew Rutenberg*

Naomi Rutenberg

James E. Sailer and

Cass Conrad*

Fannette H. Sawyer

Sidney Stern Memorial Trust

Cherida C. Smith*

Sue S. Stewart*

Katy R. Stokes and

David C. Esseks

Te-Hsiung Sun

R. M. Thomas

Angela Thompson

Miklos and Elena Toth

Judith C. and John W.

Townsend

Robert T. Tunis

Lucy R. Waletzky*

Jed Weissberg and Shelley Roth

Effie E. Westervelt

The Donald and Susan

Wilson Fund of the

Princeton Area Community

Foundation

Wichita Falls Area

Community Foundation-

John Hirschi Donor Advised

Fund

Boniface Zaino

Suzanne C. and Paul L. Zuzelo

Council Innovators

Anonymous (4)

Donald J. and Dena C. Abrams

Barry Adelman

Joel W. Ager*

William M. Alexander

Sandra D. and Ethan D.

Alyea, Jr.*

Wendy Baldwin

Ned W. and Jean Bandler*

Margaret P. Battin

David Bausch

Robert Bellucci

Richard D. and Kay Bertken

Ann Blanc

Elspeth G. Bobbs

Douglas H. Borsom

John W. Bossung

Anita Brannen

Courtney E. Broadus

Frederick and Jane Buckner*

Thomas H. Clewe

Edward M. Cohen

Mercedes B. Concepción

Roberto Cuca*

Noel de Nevers
Stanley F. and Elizabeth G.

Dole*

George Dowdall*

Sarah Engebretsen

Chet Fagin

Fred Faloona

Philip L. Ferro*

John D. and Margaret M.

Fogarty

Martha Frede

Andrew L. Frey*

Marianne Gawain-Davis

Michele L. Gerber

Richard Gerstman

Sarah Gilbert

Gorlitz Foundation, Ltd.

The Gordon and Llura Gund

Foundation*

David and Vivien W. Hanson

Guy Harris

Hayes Family Fund

Donald F. Heisel

Mary W. Heller

Susan E. Hetherington*

Thomas J. Hooley Fund for

Social Justice of The Saint

Paul Foundation

William Y. and Esther I. Hou

The Richard R. Howe

Foundation

Frederick V. Iffert

Fred C. Iklé

John Jaschke

Monwhea Jeng

Gary Jerauld

Richard S. Johnson and May

J. Reed*

Denis F. Johnston

Elise F. Jones*

Carmen and Karl A. Jungbluth*

Marion S. Kaplan

Dennis G. and Joanne G. Keith

Kevin Kraus

Linda and David Lakhdhir

Austin Lamb

Thomas A. Lehrer

Margaret J. LeMaster*

Daniel LoCascio

Robert I. and Anne F. Louttit

Joanne Lyman

Walter $\mathrm{H}$. and Ruth $\mathrm{K}$.

MacGinitie Fund

Elizabeth J. McCormack

Lauren Meserve

Batya R. Monder

Virginia P. and Robert L.

Montgomery

Ann and William T. Naftel

Charles B. Nam
We acknowledge

with gratitude that

each member of the

Population Council's

Board of Trustees

made a gift to support

the Council in 2011.

\section{Minoru Ota}

Robert H. Palmer

Kirsten Peckerman

Scott Perry

Ann Pugh

David M. and Ann Reynolds

Betsy and John Rolls*

Edward and Sharon Rubin

William Schaller

Steven Schmitt*

George F. Schnack

Jutta R. Scott*

Robert L. and Elizabeth $\mathrm{H}$. Scott*

Marianne E. Selph*

William Seltzer*

Lawrence P. Simms and

Alison G. Ho

James Simonds

Jane N. Spragg*

Craig Stine*

John K. and Elizabeth

Sullivan

Andrea Suska

John R. Taylor

Philip D. and Aija Thacher

Janet M. Throop*

Harriet B. Todd*

Michael and Marina Todd

William J. and Faith M. Towle*

George Vacek

Kathy and David G. Van Dame*

S. Jean Van Der Tak*

Deborah Weiss

Kim S. and Kathleen W. Wennesland*

Nancy C. and Mark R. Wessling*

Oliver and Helen M. Wolcott*

Barbara Yanni*

Alice M. Young

Colleen M. Zeitz and Kevin A. Lindamood

H. N. Zimmerman*

*Donors whose names are followed by an asterisk have contributed to the Population Council for at least five consecutive years. 
Mark A. Walker

Chairman

Senior Advisor

Lazard Ltd.

Paris, France

Darcy Bradbury

Managing Director

The D.E. Shaw Group

New York, New York

Peter Brandt

Stamford, Connecticut

Howard Cox

Advisory Partner

Greylock Partners

Waltham, Massachusetts

Peter J. Donaldson

President

Population Council

New York, New York

Wafaa El-Sadr

Professor of Clinical Medicine and Epidemiology

Mailman School of Public Health

Columbia University

New York, New York
Lynn A. Foster

Palm Beach, Florida

Anna Glasier

Honorary Professor

Department of Obstetrics and

Gynecology

University of Edinburgh

Edinburgh, United Kingdom

Victor Halberstadt

Professor of Public Sector Economics

University of Leiden

Netherlands

Henry L. King

Senior Counsel

Davis Polk \& Wardwell

New York, New York

Charles D. Klein

Managing Director

American Securities Capital

Partners, LLC

New York, New York

Anna Mastroianni

Professor of Law

University of Washington

School of Law

Seattle, Washington
Cheikh Mbacké

Independent Consultant

Dakar, Senegal

Robert B. Millard

Partner

Realm Partners LLC

New York, New York

Jotham Musinguzi

Regional Director

Partners in Population and

Development

Africa Regional Office

Kampala, Uganda

Anne R. Pebley

Professor

Department of Community Health Sciences

School of Public Health

University of California, Los Angeles

Los Angeles, California

K. Sujatha Rao

New Delhi, India

Elizabeth Eder Zobel de Ayala

Co-founder and Chairman

Sa Aklat Sisikat Foundation, Inc.

Manila, Philippines

\section{SENIOR MANAGEMENT}

Peter J. Donaldson

President

Mar Aguilar

Director

International Support

Ann K. Blanc

Vice President

Poverty, Gender, and Youth Program

John Bongaarts

Vice President and

Distinguished Scholar

Scott Newman

Chief Financial Officer and Treasurer
Naomi Rutenberg

Vice President

HIV and AIDS Program

James E. Sailer

Vice President

Corporate Affairs Division

John W. Townsend

Vice President

Reproductive Health Program

Patricia C. Vaughan

General Counsel and Secretary 
The Population Council confronts critical health and development issues-from stopping the spread of HIV to improving reproductive health and ensuring that young people lead full and productive lives. Through biomedical, social science, and public health research in 50 countries, we work with our partners to deliver solutions that lead to more effective policies, programs, and technologies that improve lives around the world. Established in 1952 and headquartered in New York, the Council is a nongovernmental, nonprofit organization governed by an international board of trustees.

www.popcouncil.org 


\section{POPULATION COUNCIL OFFICES}

UNIIED STATES
Headquarters
Population Council
One Dag Hammarskjold Plaza
9th Floor
New York, NY 10017 USA
Tel: +1 2123390500
Fax: +1 2127556052
E-mail: pubinfo@popcouncil.org
Center for Biomedical Research
Population Council
1230 York Avenue
New York, NY 10065 USA
Tel: +1 2123278731
Fax: +1 2123277678
E-mail: biomed@popcouncil.org
Washington, DC
Population Council
4301 Connecticut Avenue, NW
Suite 280
Washington, DC 20008 USA
Tel: +1 2022379400
Fax: +1 2022378410
E-mail: popcouncil@popcouncil.org

\section{INIERNATIONAL}

Bangladesh

Population Council

House CES (B) 21

Road 118

Gulshan, Dhaka, Bangladesh

Tel: +880-2-8821227

Fax: +880-2-8823127

E-mail: info.bangladesh@popcouncil.org

Burkina Faso

Population Council

Cité An III/ 1er Etage Pharmacie

de la Liberté

36 Avenue de la Liberté

Ouagadougou, Burkina Faso

Tel: +226-50-31-12-42

Fax: +226-50-31-12-46

E-mail: info.burkinafaso@popcouncil.org

\section{Egypt}

Population Council

59 Misr-Helwan

Agricultural Road

Maadi, Egypt

Tel: +202 25255967

Fax: +202-2525-5962

E-mail: info.wana@popcouncil.org
Ethiopia

Population Council

Heritage Plaza, 4th Floor

Bole Medhaneialem Road

Addis Ababa, Ethiopia

Tel: +251-11-663-17 12

Fax: +251-11-663-1722

E-mail: info.ethiopia@popcouncil.org

Ghana

Population Council

14B Ridge Road behind MedLab Bldg.

Roman Ridge

Accra, Ghana

Tel: +233-21-780711

Fax: +233-21-780713

E-mail: info.ghana@popcouncil.org

Guatemala

Population Council

4a. Avenida Norte, No. 15

La Antigua

Sacatepéquez, Guatemala 3001

Tel: +502-78-32-95-62

Fax: $+502-7832-9562$

E-mail: info.guatemala@popcouncil.org

India

Population Council

Zone 5A, Ground Floor

India Habitat Centre, Lodi Road

New Delhi, India 110003

Tel: +91-11-2464-2901

Fax: +91-11-2464-2903

E-mail: info.india@popcouncil.org

Kenya

Population Council

General Accident House

Ralph Bunche Road

Nairobi, Kenya

Tel: +254-20-2713-480

Fax: +254-20-2713-479

E-mail: info.nairobi@popcouncil.org

Mexico

Population Council

Avenida Cuauhtémoc no. 1400

Colonia Santa Cruz Atoyac

Delegación Benito Juárez

Mexico, DF

Mexico CP 03310

Tel: +52-55-5658-1138

E-mail: info.mexico@popcouncil.org
Nigeria

Population Council

Bassan Plaza, Block B, 3rd Floor

Plot 759, Central Business District; Off Herbert Macaulay Way

Abuja, Nigeria

Tel: +234-9-8706071

E-mail: info.nigeria@popcouncil.org

Pakistan

Population Council

House No. 7

Street No. 62 Sector F-6/3

Islamabad, Pakistan

Tel: +(92-51) 8445566

Fax: +(92-51) 2821401

E-mail: info.pakistan@popcouncil.org

Senegal

Population Council

Sacré Coeur Pyrotechnie

Appartement 2ème Etage à Droite

Dakar, Ponty

Senegal 21027

Tel: +221338595300

Fax: +221-33-824-1998

E-mail: info.senegal@popcouncil.org

South Africa

Population Council

Unit 002 \& 003 Dalefern Office Park

284 Oak Avenue, Ferndale, Randburg Johannesburg, South Africa

Tel: +27-11-781-7590

Fax: +27-11-326-1483

E-mail: info.joburg@popcouncil.org

Vietnam

Population Council

No. 41 Le Hong Phong Street

Ba Dinh District

Hanoi, Vietnam

Tel: +844-3-7345821

Fax: +844-3-7345827

E-mail: info.hanoi@popcouncil.org

Zambia

Population Council

Mwinilunga Road, Plot 4108

Sunningdale-Kabulonga

Lusaka, Zambia 10101

Tel: +260-211-262-665

Fax: +260-211-254-580

E-mail: info.zambia@popcouncil.org 